\title{
Pharmacy Students' Knowledge and Opinion of Business and Financial Management
}

\author{
Chaya Campbell ${ }^{1}$, Brittney Miller ${ }^{1}$ and Bisrat Hailemeskel ${ }^{2 *}$ \\ ${ }^{1}$ Doctor of Pharmacy Student, Howard University, Washington DC, USA \\ ${ }^{2}$ Professor, Howard University, Washington DC, USA
}

*Corresponding author: Bisrat Hailemeskel, Professor \& Vice Chair, Clinical \& Administrative Pharmacy Sciences, College of Pharmacy, Howard University, USA

\section{ARTICLE INFO}

Received: 慧 January 28, 2021

Published: 慧 February 12, 2021

Citation: Chaya Campbell, Brittney Miller, Bisrat Hailemeskel. Pharmacy Students' Knowledge and Opinion of Business and Financial Management. Biomed J Sci \& Tech Res 33(5)-2021. BJSTR. MS.ID.005466.

\section{ABSTRACT}

Introduction: Although college and post-graduate degrees are a way to ensure a brighter future with the potential to earn a higher income and better employment opportunities, assessing students' actual knowledge on finances and business is a key component on how well they will be able to achieve their dream financial goals. A study was conducted to evaluate first year professional pharmacy students' knowledge, opinion of business and financial management.

Methods: A total of 18 questions were administered to the class with 8 questions related to student demographics and the last 10 questions focusing on the participant students' knowledge on finances, their financial management skills, and their opinion of business in general. The survey was conducted via an online surveying instrument and the data was analyzed using SPSS software.

Results: There was a one hundred percent response rate from the survey of the 44 survey participants. Based on the demographic's the majority of students were between the ages of 18-34 with no students over the age of 35. Majority (59\%) of students were not native to the DMV area with $59.09 \%$ of the students having at least a 4-year degree. The financial questions confirmed that $84.9 \%$ of the class strongly and somewhat agreed that they will plan to have more than one income besides a pharmacy job postgraduation with $65.91 \%$ of students agreeing they have enough financial literacy to manage and budget their own money effectively. More than half the class (51.17\%) of students strongly or somewhat disagreed that they were confident in their knowledge of small businesses, corporations, and self-owned businesses. However, $81.82 \%$ of the class strongly or somewhat agreed they were willing to take time to learn about investing in small businesses, corporations, or self-owned businesses for profitable gain.

Conclusion: The results indicate that the majority of students have enough financial knowledge to effectively manage their own money. They plan on seeking outside sources of income besides their pharmacy jobs and are eager to gain more knowledge about investing in businesses. Although, majority of the class agreed they also had adequate knowledge in financial management of their own money, were interested in gaining more knowledge about businesses and more than half the class was interested in joining a business school or having a MBA/Pharm D to excel themselves in the business field. The results suggest that incorporating financial management into lectures or creating an elective course may be beneficial to pharmacy students.

\section{Short Communication}

The purpose of the study is to evaluate pharmacy students' knowledge and opinion of business and financial management post-graduation. Financial literacy is the ability to understand and effectively utilize various financial skills such as budgeting, financial management, and investing. A study conducted by Rangchian stated that students tended to show a weaker response to questions related 
to investments. Most pharmacy students seem to understand some parts related to financial literacy but are lacking in the investing portion. Not understanding finances may have a negative impact on students financially. However, most pharmacy students seem eager to gain more knowledge about their finances and investing. A study conducted in 2016 examined graduating pharmacy students' attitudes toward debt and association with stress, student loan debt, financial need, current employment, and post-graduation plans. A total of 147 P4 students from the University of Tennessee College of Pharmacy completed a survey one week prior to their graduation. According to the data, $90.5 \%$ of students borrowed federal loans and only $27.5 \%$ planned to pay off their loans in less than 5 years.

Increased contemplation and knowledge about loans was significantly correlated with a decreased student loan debt. This indicated students who were more knowledgeable about loans accumulated less student loan debt. The attitude of graduating students toward student loan debt have been documented but there is limited data available for first year pharmacy students. More research is needed to evaluate first year pharmacy students' attitudes on topics outside of just their knowledge about student loan debt. A strong foundation of financial literacy is needed for students to successfully apply their knowledge to stocks, investments, and loan debt after graduation. This study indicated there is a need for programming to aid students in better financial management. The results of this survey provide data in the area where students may need help in their financial lives post-graduation. The study will enable the School of Pharmacy to possibly implement opportunities and programs for students to become more financially literate in relation to financial management, budgeting and investing.

The objectives of this study are as follows:

(1) To determine pharmacy students' financial literacy;

(2) To determine pharmacy students' knowledge on small

Table 1: Response to demographics related questions $(n=44)$. businesses, corporations, self-owned business; and

(3) To determine pharmacy students' knowledge on investing their money.

\section{Methods}

A study was distributed to 44 first year pharmacy students at a college of pharmacy. The survey consisted of 18 questions. The first 8 questions were related to demographics and the last ten questions were focused on pharmacy students' knowledge and opinion of business and financial management post-graduation. The survey questions were constructed by students and distributed as a part of the Drug Information Course, which is a mandatory course for all incoming first professional year pharmacy students. The data was collected using an online survey instrument and analyzed using SPSS statistical software.

\section{Results}

A total of 44 students requested to complete the survey in this study with a one hundred percent response rate. Several demographics data including age, gender, work experience, etc. were collected and summarized in Table 1-3. Overall, more than three-quarter of the participants $(77.27 \%)$ were females. All of the survey respondents were under 35 years old with the majority (59\%) of them between the ages of 18 and 34. Over half of them came from states other than the DMV area to join Howard University's pharmacy program (HUCOP). However, the others $27.27 \%$ are residents of Maryland and one-fifth (20.45\%) are residents of Virginia. Participants were also asked if they have had at least one job, salary, and the type of job they held prior to joining HUCOP. An overwhelming number of students (95.5\%) worked before joining the pharmacy program with the greater part of the class (62.8\%) having prior work experience at a pharmacy related job. Additionally, only one-third of students replied with a non-pharmacy related job and seven students with non-healthcare related jobs.

\begin{tabular}{|c|c|c|c|}
\hline Demographic Characteristics & \multicolumn{3}{|c|}{ No \& Percent of Responses (\%) } \\
\hline Gender & Male & $18-24$ & Other \\
& $10(22.7 \%)$ & $26(59.09 \%)$ & -- \\
\hline Age (Years) & $18-24$ & $25-34$ & -34 \\
\hline Residence before Coming to HU & $26(59.09 \%)$ & $18(40.91 \%)$ & Other States \\
& $18-24$ & Virginia & $19(43.18 \%)$ \\
\hline
\end{tabular}

When asked about their annual income, over ten percent (11.3\%) were paid over $\$ 50,000$ annually while others (16.3\%) were paid less than $\$ 20,000$. The remaining $(22.56 \%)$ made between $\$ 20,000$ - $\$ 50,000$. Additionally, more than half of students worked for more than four years before attending the pharmacy program. Over one-quarter (25.6\%) of the participants reported to work over 5 years. Students were also asked to state the highest educational level achieved before joining the pharmacy program. The majority of students (59.09\%) have at least a 4-year degree, while $27.7 \%$ of students said they have some college and $4.55 \%$ have an associate degree. Interestingly, close to ten percent (9.09\%) of students said they have another professional degree including a Master of Science degree (Tables 2-4). 
Table 2: Response to job and income related questions $(n=44)$.

\begin{tabular}{|c|c|c|}
\hline Have you Worked before Coming to HU? & Response Rate (\%) & No. of Responses \\
\hline Yes & 95.45 & 42 \\
\hline No & 4.55 & 2 \\
\hline \multicolumn{3}{|l|}{ Annual Income if you have Worked } \\
\hline$\$ 10,000$ - \$19,999 & 16.28 & 7 \\
\hline$\$ 20,000-\$ 29,999$ & 6.98 & 3 \\
\hline$\$ 30,000-\$ 39,999$ & 18.6 & 8 \\
\hline$\$ 40,000$ - $\$ 49,999$ & 6.98 & 3 \\
\hline$>\$ 49,999$ & 11.3 & 5 \\
\hline \multicolumn{3}{|l|}{ Type of Job Held } \\
\hline Pharmacy Related & 62.79 & 27 \\
\hline Non-Pharmacy but health care related & 20.93 & 9 \\
\hline No-Pharmacy or Non-Health care related & 16.28 & 7 \\
\hline \multicolumn{3}{|l|}{ Number of Years Worked before Coming to HU } \\
\hline$<1$ & 16.28 & 7 \\
\hline $1-3$ & 32.56 & 14 \\
\hline $4-5$ & 25.58 & 11 \\
\hline$>5$ & 25.58 & 11 \\
\hline
\end{tabular}

Table 3: Prior educational background responses $(n=44)$.

\begin{tabular}{|c|c|c|}
\hline Highest Education Attended before Coming to HU & Response Rate (\%) & No. of Responses \\
\hline Some College & 27.7 & 2 \\
\hline 2-year degree/associate degree & 4.55 & 26 \\
\hline 4-year degree & 59.09 & 4 \\
\hline Professional degree & 9.09 & 0 \\
\hline Doctorate & 0 & 2 \\
\hline
\end{tabular}

Table 4: Survey questions response related to factors that contributed to success as a pharmacy student $(\mathrm{n}=44)$.

\begin{tabular}{|c|c|c|c|c|}
\hline Survey Questions & Strongly Agree & Somewhat Agree & Somewhat Disagree & Strongly Agree \\
\hline $\begin{array}{l}\text { I have a working knowledge to invest my money into stocks } \\
\text { after graduation }\end{array}$ & $11(25 \%)$ & $12(27.3 \%)$ & $7(15.9 \%)$ & $14(31.8 \%)$ \\
\hline $\begin{array}{l}\text { I believe I have a good understanding and knowledge of } \\
\text { banking, money, stocks, taxes, etc. }\end{array}$ & $10(22.7 \%)$ & $16(36.7 \%)$ & $7(15.9 \%)$ & $11(25 \%)$ \\
\hline $\begin{array}{l}\text { I plan to have more than one source of income besides a } \\
\text { pharmacy job after graduation }\end{array}$ & $26(59.1 \%)$ & $11(25 \%)$ & $4(9.1 \%)$ & $3(6.8 \%)$ \\
\hline $\begin{array}{l}\text { I believe I am confident in my knowledge of small } \\
\text { businesses, corporations, and self-owned businesses. }\end{array}$ & $7(16.3 \%)$ & $14(32.6 \%)$ & $12(27.9 \%)$ & $10(23.3 \%)$ \\
\hline $\begin{array}{l}\text { I believe that I have enough financial literacy to manage } \\
\text { and budget my own money effectively. }\end{array}$ & $13(29.6 \%)$ & $16(36.4 \%)$ & $10(22.7 \%)$ & $5(11.6 \%)$ \\
\hline $\begin{array}{l}\text { I will take time to learn about investing in a small business, } \\
\text { corporation, or self-owned business for profitable gain. }\end{array}$ & $24(54.6 \%)$ & $12(27.3 \%)$ & $6(13.6 \%)$ & $2(4.6 \%)$ \\
\hline $\begin{array}{l}\text { I am considering having my own pharmacy or pharmacy } \\
\text { related business in a few years after graduation. }\end{array}$ & $20(45.5 \%)$ & $16(36.4 \%)$ & $6(13.6 \%)$ & $2(4.6 \%)$ \\
\hline $\begin{array}{l}\text { I am considering joining a business school or having the } \\
\text { MBA/PharmD to help me excel as a business owner. }\end{array}$ & $10(22.7 \%)$ & $18(40.9 \%)$ & $11(25 \%)$ & $5(11.4 \%)$ \\
\hline
\end{tabular}




\section{Discussion}

After completing the survey, a little over half of the class $(52.37 \%)$ strongly agree and somewhat agree with having a working knowledge to invest money into stocks after graduation. On the other hand, the other half of the class (47.73\%) disagreed with having a working knowledge to invest money. Those who were not confident in their knowledge consisted of a little under a third of students (32\%) that strongly disagreed and $15.91 \%$ that somewhat disagreed with the survey statement. Similarly, the majority of the class $(84.9 \%)$ strongly agree and somewhat agree with planning to have more than one income besides a pharmacy job after graduation. A handful of students (6.82\%) strongly disagreed with having more than one income and the rest (9.09\%) somewhat disagreed. More than half of the class (59.09\%) also strongly agree and somewhat agree with having a good understanding and knowledge of banking overall (money, stocks, taxes, etc). Exactly $1 / 4$ of the class strongly disagreed with having a good understanding and knowledge of banking overall. The other $15.91 \%$ somewhat disagreed.

The other half of the class (51.17\%) decided they strongly disagreed and somewhat disagreed they were confident in their knowledge of small businesses, corporations, and self-owned businesses. Those who were not confident in their knowledge, either strongly disagreed (23.26\%) or somewhat disagreed (27.91\%) with the survey statement. Most students of the class (65.91\%) somewhat agree or strongly agree they have enough financial literacy to manage and budget their own money effectively. Of the students that made up the (65.91\%), 29.55\% strongly agreed and $36.36 \%$ somewhat agreed that they have enough financial literacy to manage and budget their own money effectively. Of those who disagreed, $22.73 \%$ somewhat disagreed and $11.36 \%$ strongly disagreed that they were financially literate enough to budget their own money.

\section{ISSN: 2574-1241}

DOI: $10.26717 /$ BJSTR.2021.33.005466

Bisrat Hailemeskel. Biomed J Sci \& Tech Res

cC This work is licensed under Creative Commons Attribution 4.0 License

Submission Link: https://biomedres.us/submit-manuscript.php
Almost all of the class (81.82\%) strongly agree and somewhat agree to take the time to learn about investing in a small business, corporation, or self-owned business for profitable gain. A small minority of the class (18.18\%) will not take the time to learn about investing. Only $4.5 \%$ strongly disagree with the idea and $13.64 \%$ somewhat disagree. Similar to the previous statement, a very small percentage of the class $(4.5 \%)$ strongly disagree with owning a pharmacy related business. The greater part of the class (81.81\%) strongly agrees or somewhat agrees with having their own pharmacy or pharmacy related business in a few years after graduation. The other $13.64 \%$ are somewhat against the idea. Finally, many of the students (63.64\%) strongly agree or somewhat agree with joining a business school or having the MBA/PharmD to help them excel as a business owner. Exactly $1 / 4$ of the students somewhat disagree with joining a business school or earning a MBA/PharmD. The idea was also strongly rejected by $11.36 \%$ of the students.

\section{Conclusion}

Overall, the study conducted with a ratio of $77.73 \%$ of females and $22.73 \%$ of males indicated that the mass amount of pharmacy students $(81.82 \%)$ of pharmacy students are interested in learning more about finances, investing, and business. Many students (51.17\%) "strongly disagree" that they have working knowledge about small businesses, corporations, and self-owned businesses. However, results show that the majority (59.09\%) of the survey participants felt as though they had adequate knowledge in regard to banking, money, and taxes. All in all, this study reveals that the participants show great interest in finances and want to seek other financial opportunities within or outside their pharmacy careers. In conclusion, this study will enable pharmacy schools to possibly implement opportunities and programs for students to become more financially literate in relation to financial management, businesses, budgeting and investing.

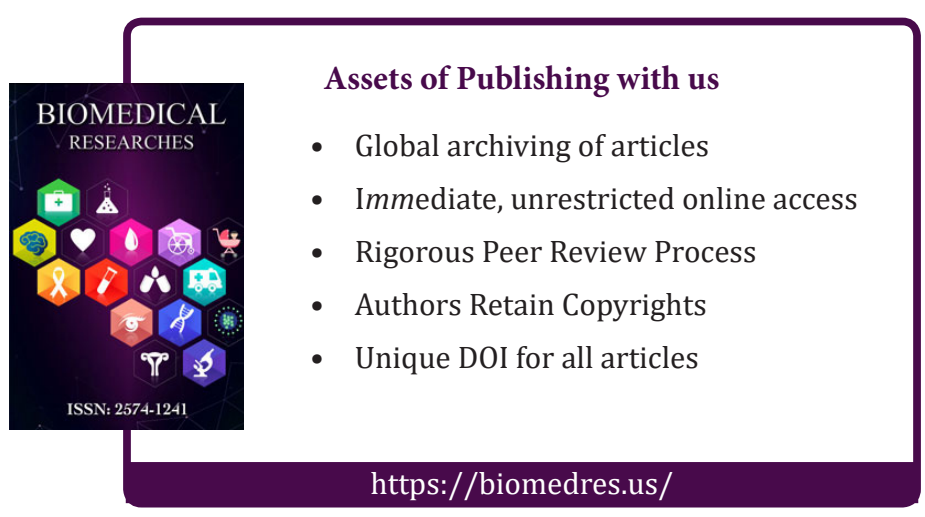

